\title{
Evaluasi Pengembangan Pegawai Di Pemerintahan Daerah (Studi Kasus di Kolaka Utara)
}

\author{
Achmad Lamo Said
}

1Program Studi Administrasi Publik, Universitas Sembilanbelas November Kolaka, Indonesia. E-mail: achmadlamosaid@gmail.com

\section{ARTICLE INFO}

Keywords:

Employee Development, Implementation of Main Tasks and Functions

Kata kunci: Pembinaan Pegawai, Pelaksanaan Tugas Pokok dan Fungsi

\section{How to cite:}

Achmad Lamo Said. (2019). Evaluasi

Pengembangan Pegawai di Pemerintah Daerah (Studi Kasus di Kolaka Utara)

5(1): $15-36$

\section{ABSTRACT}

This study aimed to find out and describe employee development in carrying out the main tasks and functions in the Education and Culture Office of North Kolaka Regency. This research is a qualitative descriptive technique through data reduction, data presentation, drawing conclusions, namely giving a comprehensive picture of the main problems discussed, especially those relating to employee development in carrying out the main tasks and functions of the North Kolaka District Education and Culture Office. The data collection techniques are direct observation, direct interviews. The results of the study show that employee training is carried out by sharing work orientation with regard to the ability, accuracy, and accuracy of employees in completing what is given by the leadership. Employee education is very concerned about attendance and attendance according to a set schedule so that it can optimize its main tasks and functions, as well as the provisions of working hours, have been carried out properly but there are still employees who are always out at work or personal matters. Employee development enhances the ability of employees to still rely on training invitations from external parties at the North Kolaka District Education and Culture Office and there are still employees whose placement is not in accordance with job competencies.

\begin{abstract}
Abstrak
Penelitian ini bertujuan untuk mengetahui dan mendeskripsikan tentang pembinaan pegawai dalam melaksanakan tugas pokok dan fungsi di Dinas Pendidikan dan Kebudayaan Kabupaten Kolaka Utara. Penelitian ini merupakan penelitian dengan teknik deskriptif kualitatif melalui reduksi data, penyajian data, menarik kesimpulan yaitu memberikan gambaran secara menyeluruh tentang masalah pokok yang dibahas khususnya yang berkaitan dengan pembinaan pegawai dalam melaksanakan tugas pokok dan fungsi di Dinas Pendidikan dan Kebudayaan Kabupaten Kolaka Utara. Adapun teknik pengumpulan data adalah observasi langsung, wawancara langsung. Hasil penelitian menunjukkan bahwa pelatihan pegawai dilakukan dengan pembagian orientasi kerja dengan memperhatikan kemampuan, kecermatan, dan ketepatan pegawai dalam menyelesaikan apa yang diberikan oleh pimpinan. Pendidikan pegawai sangat memperhatikan kehadiran dan hadir sesuai jadwal yang ditetapkan sehingga dapat mengoptimalkan tugas pokok dan fungsinya, begitu pula dengan ketetapan waktu jam kerja sudah dilaksanakan dengan baik namun masih ada pegawai yang selalu keluar dijam kerja atau ada urusan pribadi. Pengembangan pegawai peningkatan kemampuan pegawai masih mengandalkan undangan pelatihan dari pihak eksternal Dinas Pendidikan dan Kebudayaan Kabupaten Kolaka Utara serta masih ada pegawai yang penempatannya belum sesuai dengan kompetensi jabatan.
\end{abstract}

Copyright (? 2019 JAKPP. All rights reserved. 


\section{Pendahuluan}

Sumber daya manusia mempunyai peranan penting dalam aktivitas lembaga atau organisasi, karena bagaimanapun juga kemajuan dan keberhasilan suatu lembaga atau organisasi tidak lepas dari peran dan kemampuan sumber daya manusia yang baik. Meningkatnya kualitas sumber daya manusia akandapat dilihat pada kinerja pegawai dalam melaksanakan tugas dan peran yang diembannya sesuai dengan tuntutan organisasi atau lembaga, oleh karena itu upaya mengelola dan mengembangkan kinerja individu dalam organisasi menjadi hal yang sangat penting dalam membangun dan mengembangkan kemampuan organisasi untuk dapat berperan optimal dalam masyarakat.

Kinerja adalah hasil interaksi atau berfungsinya unsur-unsur motivasi, kemampuan, dan persepsi pada diri seseorang (Uno dan Nina Lamatenggo, $2012 \mathrm{~d}$ ). Sedangkan menurut Kirom, (2015), kinerja adalah merupakan bentuk penilaian tersendiri untuk mengukur tingkat keberhasilan yang di capai seseorang atau perusahaan/lembaga dalam menjalankan program-program kerjanya. Jadi prestasi kerja, yaitu hasil kerja seorang karyawan selama periode tertentu dibandingkan dengan berbagai kemungkinan, misalnya standar, target, atau kriteria yang telah ditentukan lebih dulu dan telah disepakati bersama, sehingga dapat di simpulkan bahwa kinerja adalah hasil yang dicapai oleh pegawai dalam melaksanakan tugas pokok dan fungsi yang juga dipengaruhi oleh unsur motivasi, dan kemampuan pada diri pegawai tersebut.

Lahirnya Undang-Undang No. 5 Tahun 2015 tentang Aparatur Negeri Sipil tersebut membawa perubahan mendasar guna mewujudkan sumber daya manusia aparatur yang profesional yaitu dengan pembinaan karir Pegawai Negeri Sipil yang dilaksanakan atas dasar perpaduan antara sistem prestasi kerja dan karir yang dititik beratkan pada sistem prestasi kerja yang pada hakekatnya dalam rangka peningkatan pelayanan publik. Begitu pula yang terjadi di Dinas Pendidikan dan Kebudayaan Kabupaten Kolaka Utara. Pegawai Dinas Pendidikan dan Kebudayaan Kabupaten Kolaka Utara dituntut untuk memiliki kinerja yang baik. Kinerja yang baik itu sendiri merupakan suatu potensi yang harus dimiliki oleh setiap pegawai untuk melaksanakan setiap tugas dan tanggung jawab yang diberikan. Dengan kinerja yang baik, maka setiap pegawai dapat menyelesaikan segala beban lembaga dengan efektif dan efisien sehingga masalah-masalah yang terjadi pada lembaga dapat teratasi dengan baik. Pegawai diharapkan dapat memaksimalkan tanggung jawab dengan berbekal pada kemampuan yang berkaitan dengan implementasi pekerjaan mereka. Kinerja pegawai dapat dilihat dari aspek kuantitas kerja, ketepatan kerja dan kualitas kerja serta tingkat kemampuan dalam bekerja, kemampuan mencari, mengolah dan menganalisis data, serta kemampuan mengevaluasi.

Berbicara tentang kualitas pegawai, maka pembinaan kinerja memberikan sumbangan sangat berarti bagi kesuksesan dan kelancaran dalam pekerjaan. Pada dasarnya pembinaan merupakan proses yang berlanjut dan bukan proses sesaat saja terutama disaat perkembangan teknologi dan pengetahuan berkembang pesat 
seperti saat ini, peran pembinaan kinerja pegawai sangat besar untuk membekali pegawai agar lebih kreatif dalam mencapai tujuan lembaga secara efektif dan efisien. Penelitian telah dilakukan oleh Hamjadid (2010) mengenai Manajemen Pengembangan Sumber Daya Manusia di Dinas Pendidikan dan Kebudayaan Kabupaten Kolaka Utara. Identifiksi masalah yang ditemukan antara lain penyelenggaraan pendidikan di Kabupaten Kolaka Utara yang belum baik, Dinas Pendidikan dan Kebudayaan Kabupaten Kolaka Utara belum optimal dalam memajukan pendidikan, kinerja pegawai belum maksimal, banyak pegawai yang tidak memiliki kompetensi sesuai dengan bidang tugasnya, namun kesempatan pemberdayaan pegawai kurang dimanfaatkan oleh para pegawai, dan manajemen pengembangan sumber daya manusia belum terjalin dengan baik.

Pengembangan kemampuan lembaga melalui pembinaan pegawai yang diarahkan pada makin terwujudnya keterpaduan tugas dan fungsi penyelenggaraan manajemen dan untuk mewujudkan sistem administrasi yang makin handal, profesional, efisien, dan efektif serta tanggap terhadap aspirasi rakyat dan terhadap dinamika perubahan strategis.Pembinaan pegawai pada prinsipnya merupakan suatu usaha untuk mengembangkan, meningkatkan dan mengarahkan pegawai agar didalam bekerja timbul kegairahan kerja dan mempunyai rasa tanggung jawab yang besar. Dengan pembinaan yang baik akan memotivasi pegawai untuk bekerja lebih giat atau semangat serta penuh rasa tanggung jawab.

Beberapa diantara pembinaan tersebut antara lain pembinaan karir, pembinaan disiplin, pembinaan pendidikan dan pelatihan. Upaya pembinaan tersebut terkait erat dengan pergeseran fungsi dan peranan pegawai yang lebih menjurus ke arah profesionalisasi kerja dan pemberi kemudahan (fasilitator) administrasi dan pelayanan (service provider). Menurut Yuniarsih, (2009), pengembangan sumber daya manusia merupakan salah satu fungsi operasional manajemen sumber daya manusia yang berisi kegiatan-kegiatan untuk memelihara dan meningkatkan kompetensi pegawai melalui peningkatan pengetahuan. Misalnya, dilakukan untuk meningkatkan keterampilan lewat latihan (training), yang diperlukan untuk dapat menjalankan tugas dengan baik. Kegiatan ini makin menjadi penting karena berkembangnya teknologi, dan makin kompleksnya tugas-tugas manajer.

Pembinaan yang segera dapat dilakukan adalah peningkatan kemampuan atau kompetensi yang dilakukan melalui pendidikan dan pelatihan (diklat) maupun non diklat. Pembinaan melalui diklat dapat dilakukan dengan melakukan berbagai kursus, pendidikan formal maupun non formal atau pendidikan lainnya yang berkaitan dengan peningkatan kemampuan atau kompetensi teknis maupun perubahan pola pikir, moral, dan perilaku pegawai. Meskipun merubah pola pikir, moral dan perilaku pegawai melalui diklat memang tidak mudah, akan tetapi tetap perlu dilakukan. Sementara peningkatan kemampuan atau kompetensi melalui non diklat dapat dilakukan dengan menciptakan situasi dan kondisi kerja yang kondusif untuk terjadinya peningkatan kemampuan, melakukan mutasi secara berkala, menciptakan hubungan antar personal yang harmonis dan lain sebagainya. Peningkatan kompetensi pegawai dalam mengemban tugas atau jabatan birokrasi melalui diklat adalah berorientasi pada standar kompetensi jabatan sesuai tantangan 
reformasi dan globalisasi yang tentu saja disesuaikan dengan kebutuhan stakeholder.

Pembinaan karir pegawai di Dinas Pendidikan dan Kebudayaan Kabupaten Kolaka Utara sendiri masih belum dioptimalkan karena sistem kenaikan pangkat yang diberlakukan selama ini masih bersifat administrasi dan masih belum dikaitkan dengan prestasi kerja yang dihasilkan pegawai. Penyebabnya antara lain kelemahan sistem pengukuran kinerja sehingga pegawai yang berprestasi kurang mendapat perhatian dan penghargaan yang adil. Pegawai yang prestasi kerjanya kurang bagus masih memungkinkan untuk naik pangkat atau golongan secara berkala sesuai ketentuan begitu pula dengan pegawai yang memiliki prestasi yang bagus sehingga kurang adanya penghargaan kepada pegawai yang berprestasi. Kesempatan peningkatan kemampuan pegawai di Dinas Pendidikan dan Kebudayaan Kabupaten Kolaka Utara melalui diklat ataupun bimtek masih terbatas.

Pelatihan pegawai dilakukan dengan pembagian orientasi kerja dengan memperhatikan kemampuan, kecermatan, dan ketepatan pegawai dalam menyelesaikan apa yang diberikan oleh pimpinan Pendidikan pegawai sangat memperhatikan kehadiran dan hadir sesuai jadwal yang ditetapkan sehingga dapat mengoptimalkan tugas pokok dan fungsinya, begitu pula dengan ketetapan waktu jam kerja sudah dilaksanakan dengan baik namun masih ada pegawai yang selalu keluar dijam kerja atau ada urusan pribadi.

Melihat besarnya peran sumber daya manusia dalam pencapaian tujuan organisasi, maka hadirnya pegawai yang memiliki kecakapan dan ketrampilan sangat dibutuhkan. Untuk itulah sumber daya manusia dalam suatu organisasi termasuk organisasi pendidikan memerlukan pengelolaan dan pengembangan yang baik dalam melaksanakan tugas dan perannya agar dapat memberikan kontribusi optimal dalam upaya meningkatkan kinerja organisasi, sehingga mereka dapat memberi sumbangan yang makin meningkat bagi pencapaian tujuan.

Dengan berbagai realita yang ditemui di Dinas Pendidikan dan Kebudayaan Kabupaten Kolaka Utara, dapat ditarik suatu dasar pemikiran bahwa banyaknya permasalahan yang menghambat kinerja pegawai di Dinas Pendidikan dan Kebudayaan Kabupaten Kolaka Utara dalam melaksanakan tugas pokok dan fungsi menjadikannya tidak optimal, sehingga adanya suatu pembinaan kinerja pegawai dalam menunjang pelaksanaan tugas pokok dan fungsi.

Dari berbagai permasalahan terkait kinerja pegawai tersebut, maka peneliti tertarik untuk melakukan penelitian tentang pembinaan kinerja pegawai. Untuk mewujudkan pegawai yang profesional dan berkompetensi pendidikan dan pelatihan pegawai yang dilaksanakan atas dasar perpaduan antara sistem prestasi kerja, maka pengembangan pegawai berbasis kompetensi merupakan suatu upaya yang dilakukan agar organisasi dapat mewujudkan kinerja yang lebih baik dan memberikan pelayanan publik yang terbaik. 


\section{Kajian Literatur}

Dalam suatu organisasi atau perusahaan peranan pengelolaan sumber daya manusia sangatlah penting. Hal ini dapat kita mengerti karena tanpa sumber daya manusia, suatu organisasi tidak mungkin berjalan. Dengan semakin berkembangnya suatu organisasi maka makin sulit pula perencanaan dan pengendalian pegawainya. Oleh karena itu, maka sangatlah dibutuhkan manajemen personalia yang mengatur dan mengatasi masalah-masalah yang berhubungan dengan kepegawaian, baik dalam hal administrasi, pembagian tugas maupun pada kegiatan personalia lainnya.

Manajemen Personalia adalah perencanaan, pengorganisasian, pengarahan, dan pengawasan dari pengadaan, pengembangan, pemberian kompensasi, pengintegrasian dan pemeliharaan tenaga kerja dengan maksud untuk membantu mencapai tujuan perusahaan, individu dan masyarakat Husnan, (2002). Sedangkan di dalam dunia pendidikan, manajemen personalia dikenal dengan administrasi personel sekolah. Sukirman (2009) mendefinisikan secara operasional, administrasi personel sekolah adalah segenap proses penataan yang bersangkut paut dengan masalah memperoleh dan menggunakan tenaga kerja untuk dan di sekolah secara efisien, demi tercapainya tujuan sekolah yang telah ditentukan sebelumnya.

Menurut Sukirman (2009) ruang lingkup administrasi personel pendidikan khususnya sekolah, yaitu segenap proses penataan pegawai meliputi semua proses atau cara memperoleh pegawai, penempatan dan penugasan, pemeliharaannya, pembinaannya, evaluasi, serta pemutusan hubungan kerja.

Pembinaan menekankan pada pendekatan praktis, pengembangan sikap kemampuan dan kecakapan. Berkenaan dengan hal tersebut, tentang pengembangan sumber daya manusia yang bahwa bila hal ini terapkan pada suatu departemen maka dapat di tarik kesimpulan bahwa pusat pendidikan dan pelatihan (pusdiklat), pegawai departemen mempunyai tiga fungsi pokok yakni:

1. Pelatihan pegawai (emplyee devoloment) yakni pelatian-pelatihan para tenaga untuk meningkatkan kemampuan pengelolaan program-program dan teknis fungsional program-program yang bersangkutan. Pelatihan-pelatihan ini bersifat peningkatan kemampuan tugas di bidangnya masing-masing.

2. Pendidikan pegawai (employee education) yaitu kegiantan-kegiatan pendidikan atau pelatihan yang bersifat promosi dan pengembangan karier bagi para pegawai. Oleh sebab itu fokus pada pendidikan pegawai ini adalah pengembangan kemampuab individual pegawai.

3. Pembangunan pegawai (employee develompment) yaitu kegiatan pendidikan atau pelatihan pegawai yang di tujukan kepada pengembangan, pertumbuhan, perbahan departemen atau unit-unit kerja departement. Melalu 
kegiatan ini para pegawai berkembang secara fleksibel seirama perkembangan ke masa depan.

Upaya pimpinan dalam melakukan pembinaan juga tercantum dalam Peraturan Pemerintah Republik Indonesia Nomor 65 Tahun 2005 Tentang Pedoman Penyusunan Dan Penerapan Standar Pelayanan Minimal dengan maksud agar otonomi daerah dapat dilaksanakan sejalan dengan tujuan yang hendak dicapai, Pemerintah wajib melakukan pembinaan dan pengawasan berupa pemberian pedoman, standar, arahan, bimbingan, pelatihan, supervisi, pengendalian, koordinasi, monitoring dan evaluasi. Hal ini dimaksudkan agar kinerja penyelenggaraan pemerintahan daerah tetap sejalan dengan tujuan nasional dalam kerangka Negara Kesatuan Republik Indonesia. Pada pasal 14 yang menyebutkan tentang pembinaan yaitu pimpinan lembaga melakukan pembinaan berupafasilitasi, pemberian orientasi umum, petunjuk teknis, bimbingan teknis, pendidikan dan pelatihan atau bantuan teknis lainnya.

Menurut Mangkunegara (2005 : 9) kinerja pegawai adalah hasil kerja secara kualitas dan kuantitas yang dicapai oleh seseorang pegawai dalam melaksanakan tugasnya sesuai dengan tanggung jawab yang diberikan kepadanya dapat diukur dari :

1. Pengetahuan tentang pekerjaan

2. Kualitas kerja

3. Produktivitas

4. Adaptasi

5. Inisiatif dan pemecahan masalah

6. Kerjasama

7. Tanggungjawab

8. Kemampuan berkomunikasi dan berinteraksi

Dalam suatu organisasi memang diperlukan adanya penilaian kinerja. Organisasi pemerintahan pun mengutamakan penilaian kinerja sebagai tolak ukur seberapa jauh pegawai atau keryawan melaksanakan tugas untuk mencapai hasil kerja dari organisasi tersebut. Menurut Ruky (2004 : 45) ada beberapa faktor untuk mengukur kinerja pegawai, yaitu :

1. Kemampuan pegawai

2. Disiplin pegawai

3. Pelayanan yang diberikan

Selanjutnya menurut Mahmudi (2005 : 7) pengukuran kinerja paling tidak harus mencakup tiga variabel yang dipertimbangkan, yaitu :

1. Perilaku (proses)

2. Output ( produk langsung suatu aktivitas atau program ), dan

3. Outcome (Value Added atau dampak aktivitas/program)

Sasaran kinerja yang menetapkan adalah spesifik dalam bidang proyek, proses, kegiatan rutin dan inti yang akan menjadi tanggung jawab pegawai (Foster, 2001 : 6). Sasaran kinerja adalah kinerja pegawai, sehingga diperoleh informasi yang akurat tentang kinerja tersebut, apakah memuaskan atau tidak. 
Unit-unit tingkat bawah mungkin telah menjadi sasaran yang mereka tetapkan, dan sebaliknya mereka yang dipuncak mungkin belum memenuhi sasaran. Unsur-unsur yang perlu digunakan dalam mengukur kinerja pegawai, menurut Sedarmayanti (2001 : 21) adalah sebagai berikut :

1. Kekinerjaan, yakni menilai kinerja pegawai dalam mematuhi peraturan yang ada dan mengerjakan pekerjaan sesuai dengan instruksi yang diberikan oleh atasan.

2. Tanggung jawab, yakni menilai kesediaan pegawai dalam mempertanggungjawabkan pekerjaan dan hasil kerjanya.

3. Kejujuran, yakni menilai kejujuran dalam menjalankan tugas-tugasnya.

4. Kemampuan bekerja sama, yakni menilai kesediaan pegawai dalam berpatisipasi dan bekerja sama dengan pegawai lainnya, sehingga hasil pekerjaan semakin baik.

5. Kesetiaan, yakni menilai kesetiaan pegawai dalam pekerjaan dan jabatannya dalam perusahaan.

6. Ketelitian kerja, yakni menilai ketelitian dalam melaksanakan penyelesaian pekerjaannya.

7. Inisiatif, yakni menilai kemampuan pegawai dalam menciptakan hal-hal yang baru dalam mensukseskan pekerjaannya.

8. Kondisi fisik, yakni menilai stamina pegawai dalam melaksanakan tugasnya.

9. Kepemimpinan, yakni menilai kemampuan pegawai untuk memimpin dan memotivasi orang lain untuk bekerja.

10. Kemampuan mengambil keputusan, yakni menilai kemampuan pegawai dalam mengambil suatu keputusan dalam suatu keadaan.

11. Kecakapan, yakni menilai hasil kerja pegawai baik kulitas maupun kuantitas yang dapat dihasilkan

Penilaian kinerja adalah proses pengukuran kinerja seseorang. Penilaian kinerja merupkan pengawasan terhadap kualitas personal. Peniliaian kinerja (performance appraisa) pada dasarnya merupakan salah satu faktor kunci ganda mengembangkan suatu organisasi secara efektif dan efesien, karena adanya kebijakan atau program penilaian prestasi kerja.

Menurut Husnan (2002) adapun manfaat yang bisa didapat dari penilaian kinerja adalah :

1. Perbaikan kinerja karyawan yaitu sebagai umpan balik bagi karyawan, manajer dan departemen personalia untuk mengoreksi kegiatan-kegiatannya dalam perbaikan kinerja

2. Penyesuaian kompensasi yaitu membantu pengambil keputusan dalam menentukan upah, kenaikan upah, bonus dan kompensasi lainnya.

3. Keputusan penempatan yaitu kinerja masa lalu menjadi dasar untuk mutasi, promosi, transfer, demosi dan sebagainya.

4. Kebutuhan latiahn dan pengembangan yaitu kinerja yang kurang bisa dibenahi dengan cara pelatihan, dari penilaian kinerja dapat ditentukan pelatihan apa yang sesuai dan dibutuhkan. 
5. Perencanaan dan pengembangan karir yaitu umpan balik bagi pengambil keputusan mengenai jalur karir yang ada di perusahaan dan keputusan karir lainnya.

6. Penyimpangan proses staffing yaitu prestasi kerja menjadi cermin kuat lemahnya prosedur staffing departemen personalia.

7. Ketidakakuratan informasi yaitu penilaian secara langsung akan memberi data yang lebih akurat untuk analisa jabatan, rencana-rencana sumber daya manusia, atau komponen lain dalam sistem informasi manajemen personalia.

8. Kesalahan desain pekerjaan yaitu desain yang salah bisa meengakibatkan kinerja yang rendah, penilaian kinerja bisa membantu mendiagnosa apakah ada kesalahan desain kerja.

9. Kesempatan kerja yang adil yaitu penilaian kinerja yang akurat akan menjamin keputusan penempatan internal yang tidak diskriminatif.

10. Tantangan eksternal yaitu kinerja rendah yang diakibatkan oleh faktor eksternal sebaiknya diketahui perusahaan, sehingga ada kemungkinan perusahaan dapat membantu penyelesaiannya

\section{Metode Penelitian}

Penelitian ini dilakukan di Dinas Pendidikan dan Kebudayaan Kabupaten Kolaka Utara, karena pada instansi tersebut masih banyak pegawai tidak disiplin dan tidak tertarik pada pendidikan dan pelatihan-pelatihan yang sifatnya eksternal. Narasumber pada penelitian ini adalah kepala Dinas Pendidikan dan Kebudayaan, kepala sub bidang, kepala bidang, kepala seksi, dan pegawai dinas pendidikan dan kebudayaan kabupaten kolaka utara. Penelitian ini menggunakan metode deskriptif dengan pendekatan kualitatif. Menurut Nazir (2011), menyatakan bahwa metode deskriptif adalah suatu metode dalam meneliti status sekelompok manusia, suatu objek, suatu set kondisi, suatu sistem pemikiran, ataupun suatu kelas peristiwa pada masa sekarang, penelitian kualitatif adalah penelitian yang bermaksud untuk memahami fenomena tentang apa yang dialami oleh subjek penelitian misalnya perilaku, persepsi, motivasi, tindakan, secara holistic, dan dengan cara deskripsi dalam bentuk kata-kata dan bahasa, pada suatu konteks khusus yang alamiah dan dengan memanfaatkan berbagai metode alamiah.

Jenis data yang digunakan adalah data primer dan data sekunder dengan teknik pengumpulan melalui penelitian di lapangan dan studi kepustakaan. Studi kepustakaan berkaitan dengan kajian teoritis dan referensi lain yang berkaitan dengan nilai, budaya dan norma yang berkembang pada situasi sosial yang diteliti, selain itu studi kepustakaan sangat penting dalam melakukan penelitian, hal ini dikarenakan penelitian tidak akan lepas dari literatur-literatur ilmiah (Sugiyono, 2016). Studi lapangan ditempuh dengan cara :

1. Observasi, dilakukan peneliti dengan mengumpulkan beberapa data terkait dengan pendidikan dan pelatihan dalam pengembangan pegawai di Pemerintah Daerah Kabupaten Kolaka Utara yang kemudian disajikan secara sistematis untuk menggambarkan objek yang diteliti; 
2. Wawancara, dengan wawancara peneliti dapat secara langsung mengetahui permasalahan seperti apa kondisi pegawai di Pemerintah Daerah Kabupaten Kolaka Utara

3. Kemudian dokumentasi di perlukan peneliti sebagai catatan peristiwa pada saat itu sebagai bahan pendukung dan pembanding dalam penulisan karya ilmiah ini

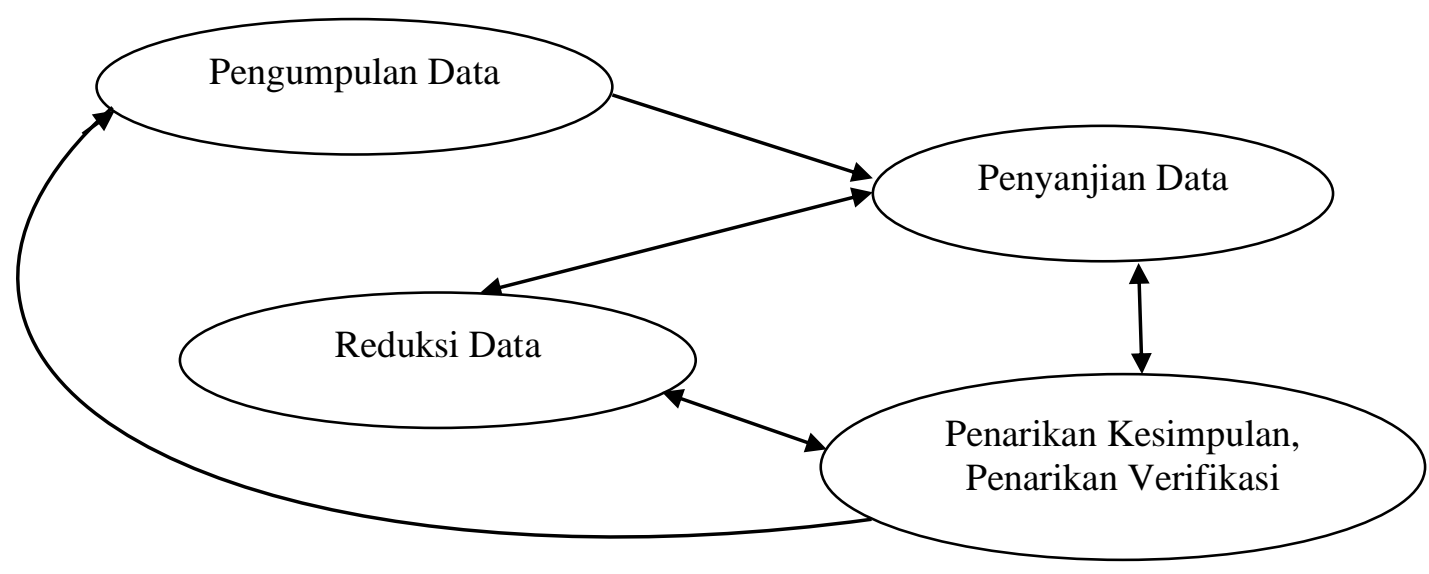

Gambar 1. Teknik analisis data berdasarkan Miles dan Huberman (1992:20)

\section{Hasil dan Pembahasan}

Pengembangan kemampuan lembaga melalui pembinaan pegawai yang diarahkan pada makin terwujudnya keterpaduan tugas dan fungsi penyelenggaraan manajemen dan untuk mewujudkan sistem administrasi yang makin handal, profesional, efisien, dan efektif serta tanggap terhadap aspirasi rakyat dan terhadap dinamika perubahan strategis. Menurut Mautina (1994) menjelaskan tentang pembinaan yaitu, pembinaan pegawai pada prinsipnya merupakan suatu usaha untuk mengembangkan, meningkatkan dan mengarahkan pegawai agar didalam bekerja timbul kegairahan kerja dan mempunyai rasa tanggung jawab yang besar. Dengan pembinaan yang baik akan memotivasi pegawai untuk bekerja lebih giat atau semangat serta penuh rasa tanggung jawab.

Beberapa diantara pembinaan tersebut antara lain pembinaan karir, pembinaan disiplin, pembinaan pendidikan dan pelatihan. Upaya pembinaan tersebut terkait erat dengan pergeseran fungsi dan peranan pegawai yang lebih menjurus ke arah profesionalisasi kerja dan pemberi kemudahan (fasilitator) administrasi dan pelayanan (service provider). Menurut Husnan (2002) pengembangan ini dilakukan untuk meningkatkan keterampilan lewat latihan (training), yang diperlukan untuk dapat menjalankan tugas dengan baik.kegiatan ini makin menjadi penting karena berkembangnya teknologi, dan makin kompleksnya tugas-tugas manajer.

Pembinaan yang segera dapat dilakukan adalah peningkatan kemampuan atau kompetensi yang dilakukan melalui pendidikan dan pelatihan (diklat) maupun non diklat. Pembinaan melalui diklat dapat dilakukan dengan 
melakukan berbagai kursus, pendidikan formal maupun non formal atau pendidikan lainnya yang berkaitan dengan peningkatan kemampuan atau kompetensi teknis maupun perubahan pola pikir, moral, dan perilaku pegawai. Meskipun merubah pola pikir, moral dan perilaku pegawai melalui diklat memang tidak mudah, akan tetapi tetap perlu dilakukan. Sementara peningkatan kemampuan atau kompetensi melalui non diklat dapat dilakukan dengan menciptakan situasi dan kondisi kerja yang kondusif untuk terjadinya peningkatan kemampuan, melakukan mutasi secara berkala, menciptakan hubungan antar personal yang harmonis dan lain sebagainya. Peningkatan kompetensi pegawai dalam mengemban tugas atau jabatan birokrasi melalui diklat adalah berorientasi pada standar kompetensi jabatan sesuai tantangan reformasi dan globalisasi yang tentu saja disesuaikan dengan kebutuhan stakeholder.

Secara umum pembinaan diartikan sebagai usaha untuk memberikan pengarahan dan bimbingan guna mencapai suatu tujuan tertentu. Pembinaan merupakan hal yang umum yang digunakan untuk meningkatkan pengetahuan, sikap, kecakapan di bidang pendidikan, ekonomi, social, kemasyarakatan, dan lainnya. Pembinaan menekankan pada pendekatan praktis, pengembangan sikap kemampuan dan kecakapan.Berkenaan dengan hal tersebut, sesuai dengan Poerwadarminta (1987) bahwa "Pembinaan adalah yang dilakukan secara sadar, terencana, teratur dan terarah untuk meningkatkan pengetahuan, sikap dan keterampilan subjek dengan tindakan pengarahan dan pengawasan untuk mencapai tujuan".

Menurut Sudjana (2004) menjelaskan ruang lingkup pembinaan yaitu, pembinaan meliputi dua sub-fungsi yaitu pengawasan (controlling) dan supervisi (supervising). Secara umum, persamaan antara pengawasan dan supervisi ialah bahwa keduanya merupakan bagian dari kegiatan pembinaan sebagai fungsi manajemen. Perbedaannya dijelaskan oleh Ametembun tentang perbedaan konsep pengawasan (inspeksi) dan supervisi.Inspeksi merupakan jabatan dalam suatu instansi pendidikan, seperti pengawas yang mempunyai tugas untuk memeriksa pelaksanaan segala instruksi dan peraturan yang telah ditetapkan. Pengawasan dilaksanakan berdasarkan prinsip otokrasi. Sedangkan yang disebut supervisi adalah fungsi untuk membina situasi penyelenggaraan kegiatan melalui upaya pelayanan, bantuan, dan bimbingan ke arah perbaikan situasi secara menyeluruh.

Secara umum pembinaan diartikan sebagai usaha untuk memberikan pengarahan dan bimbingan guna mencapai suatu tujuan tertentu. Pembinaan merupakan hal yang umum yang digunakan untuk meningkatkan pengetahuan, sikap, kecakapan di bidang pendidikan, ekonomi, social, kemasyarakatan, dan lainnya. Pembinaan menekankan pada pendekatan praktis, pengembangan sikap kemampuan dan kecakapan. Berkenaan dengan hal tersebut, sesuai dengan yang dikemukakan oleh Notoatmodjo (2003) tentang pengembangan sumber daya manusia yang mengatakan bahwa bila hal ini terapkan pada suatu departemen maka dapat di tarik kesimpulan bahwa pusdiklat pegawai departemen mempunyai tiga fungsi pokok yakni: 


\section{Pelatihan Pegawai}

Dalam rangka upaya meningkatkan mutu, keterampilan kerja, memupuk kegairahan kerja atau semangat kerja pegawai, maka pembinaan pegawai harus dilaksanakan atas dasar perpaduan sistem karir dan sistem prestasi kerja. Pembinaan karir pegawai meliputi upaya apa saja yang dilakukan oleh pimpinan dalam rangka melakukan pembinaan kepada pegawai di Kantor Dinas Pendidikan dan Kebudayaan Kabupaten Kolaka Utara.

Pembinaan karir pegawai dalam Melaksanakan Tugas Pokok dan Fungsi di Dinas Pendidikan dan Kebudayaan Kabupaten Kolaka Utara. Pembinaan dilakukan secara terencana dan terarah untuk meningkatkan kesetiaan, ketaatan, pengetahuan, keterampilan, sikap dan tingkah laku pegawai, disiplin pegawai yang bertujuan untuk menghasilkan tenaga kerja yang berdaya guna dan berhasil guna sehingga dapat mencapai suatu proses, hasil, atau pernyataan menjadi lebih baik. Tujuan dari adanya kegiatan pembinaan adalah untuk merangsang kedisiplinan dan moral kerja pegawai yang dilakukan secara efektif guna mencegah atau mengetahui kesalahan, memberikan solusi, memelihara kedisiplinan, meningkatkan prestasi kerja dan juga mengaktifkan peranan pimpinan dan pegawai.

Dengan adanya pembinaan pegawai di Dinas Pendidikan dan Kebudayaan Kabupaten Kolaka Utara, pimpinan secara langsung dapat mengetahui kemampuan dan kedisiplinan setiap pegawai, sehingga kondisi pegawai dapat dinilai obyektif. Disamping itu pembinaan juga menuntut adanya kebersamaan aktif antara pimpinan dan pegawai dalam mencapai tujuan lembaga dan masyarakat. Berikut adalah upaya pimpinan dalam pembinaan karir pegawai yang meliputi: proses pemberian orientasi umum, memfasilitasi kebutuhan pegawai, mensosialisasikan petunjuk teknis hingga ke tingkat pelaksana, proses promosi, laternal, dan mutasi pegawai secara terencana, serta kesempatan peningkatan kemampuan, dan mengikut sertakan pegawai dalam bimbingan teknis, pendidikan dan pelatihan serta pemberian tugas khusus kepada pegawai di Dinas Pendidikan dan Kebudayaan Kabupaten Kolaka Utara

Proses pemberian orientasi di kantor Dinas Pendidikan dan Kebudayaan Kabupaten Kolaka Utara dimulai dari perkenalan antara pegawai dengan pegawai lain, pegawai dengan pimpinan, lalu dilakukan pemahaman akan struktur organisasi, masalah-masalah organisasional, hak dan kewajiban pegawai, sampai dengan pemahaman akan tugas pokok dan fungsi. Pemberian orientasi umum di Dinas Pendidikan dan Kebudayaan Kabupaten Kolaka Utara lebih terlihat pada penjelasan tentang hak dan kewajiban pegawai serta pemahaman tentang tugas pokok dan fungsi. Proses orientasi merupakan bentuk proses pelimpahan wewenang dari pimpinan kepada pegawai. Dalam pelimpahan wewenang, didalamnya terjadi proses komunikasi dan koordinasi.

Komunikasi dan koordinasi di Dinas Pendidikan dan Kebudayaan Kabupaten Kolaka Utara secara struktural. Tetapi, tidak menutup kemungkinan bahwa pimpinan akan melakukan panggilan langsung kepada staf. Hal ini terjadi 
jika muncul permasalahan-permasalahan khusus yang apabila dipertimbangkan, bobot permasalahan tersebut menjadi masalah yang serius. Selanjutnya proses evaluasi yang dilakukan melalui fungsi kontrol oleh pimpinan dengan meminta laporan secara berkala. Setelah dilakukan proses evaluasi pada masing-masing tugas yang dibebankan, maka dapat diketahui kurangnya kompetensi pada pelaksanaan di bagian apa dan nantinya akan ditindak lanjuti dengan pembinaan. Tugas pokok dan fungsi pegawai di Dinas Pendidikan dan Kebudayaan Kabupaten Kolaka Utara. Petikan wawancara tentang pemberian orientasi umum yang oleh Bapak MI, sebagai berikut :

"Komunikasi dan koordinasi tentang tugas dan pekerjaan secara struktural. Dapat dilihat sesuai bagan organisasinya seperti apa. Tapi juga tidak menutup kemungkinan, Saya melakukan panggilan langsung kepada pegawai jika ada permasalahan khusus. Itu kalau tentang masalah, kalau tentang tugas biasanya kami melakukan evaluasi, kurangnya pelaksanaan kegiatan itu dimana, baru kami melakukan upaya pembinaan yang seperti apa." (Wawancara, 6 Agustus 2018)

Pemberian orientasi umum oleh pimpinan tersebut ditegaskan juga pada kesempatan wawancara lainnya dengan Bapak SI, sebagaimana pernyataan sebagai berikut:

"Pimpinan meluangkan waktunya untuk berada di kantor dan juga melakukan rapat rutin. Dengan adanya rapat tersebut, pegawai akan dapat menyampaikan apa saja kesulitannya dalam melakukan pekerjaan sehingga pimpinan dapat mengevaluasi serta mencari jalan keluar dari permasalahan tersebut. Dengan adanya rapat itu dapat menghindari misscommunication antara pimpinan dan pegawainya serta adanya pembagian kerja/job description yang jelas. (Wawancara, 8 Agustus 2018)

Sedangkan untuk proses orientasi dijelaskan secara terperinci oleh Bapak Ma dalam suatu sesi wawancara dengan beberapa tahap. Langkah pertama yaitu memberikan penjelasan tentang tupoksi. Selanjutnya dijelaskan tentang mekanisme dan prosedur kerja untuk menyelesaikan tugas-tugas di bidang secara komprehensif. Proses pembagian kerja dilakukan oleh kepala Bidang yang memberikan arahan kepada Kepala Seksi yang lalu akan diteruskan kepada pegawai. Hal ini terjadi secara struktural. Pembagian kerja juga dilakukan secara proporsional agar pemanfaatan waktu dapat dimaksimalkan. Dalam menyelesaikan pekerjaan yang diberikan selalu berdasarkan pada Surat Keputusan berasal dari Bupati yang dijabarkan dalam Tupoksi. Menurut Bapak Ma yang diwawancarai pada suatu kesempatan, seperti berikut:

"Pemberian orientasi ini, berhubung semua pegawainya sudah cukup lama bekerja disini. Jadi prosesnya cuma penjelasan tentang tupoksinya. Pegawai harus mengerjakan apa. Saya sampaikan kepada Kasie. Nanti Kasie menyampaikan kepada pegawai yang diberi beban kerja. Beban kerja juga dibagi secara proporsional. Biar maksimal dalam melaksanakan tugas pokoknya masing-masing. (Wawancara, 6 Agustus 2018) 
Sedangkan di Bidang Pendidikan Masyarakat dan Kebudayaan, lebih mengarah pada pembagian tugas yang dilakukan dengan mempertimbangkan kemampuan, kecermatan, dan ketepatan pegawai dalam melaksanakan pekerjaan. Sehingga penyelesaian pekerjaan yang dilakukan oleh pegawai dapat secara efektif dan efisien. Berbagai kemampuan harus dikuasai oleh pegawai agar pegawai bisa dengan tepat menyelesaikan apa yang menjadi kewajiban. Selain harus mampu menguasai kemampuan teknis, kemampuan manajerial juga harus dikuasai oleh Kepala Bidang dan Kepala Seksi. Untuk kemampuan teknis sudah seharusnya dikuasai oleh pegawai. Petikan wawancara oleh bapak HL tentang pemberian orientasi umum, sebagai berikut:

"Pembagian tugas itu memperhatikan kemampuan, kecermatan, dan ketepatan pegawai dalam menyelesaikan apa yang diberikan oleh pimpinan, Biar efektif efisien tidak kerja dua kali. Kemampuan pegawai secara teknis kalau di Bidang ini. Sedangkan untuk Kasie juga harus punya kemampuan manajerial dalam melaksanakan tugasnya. (Wawancara, 6 Agustus 2018)

Proses orientasi yang dilakukan di Dinas Pendidikan dan Kebudayaan diungkapkan oleh Kepala Dinas dalam suatu sesi wawancara. Proses orientasi pegawai melalui berbagai cara antara lain:

1. Membudayakan sapa, salam, dan membangun komunikasi yang intensif antara pimpinan dan pegawai.

2. Memantau progres pekerjaan yang diberikan dan selalu kontinyu bertanya dan meminta laporan akan pelaksanaan program kepada pegawai.

3. Selalu mengkomunikasikan hambatan, dan mencari solusi yang akan membantu penyelesaian pekerjaan pegawai.

4. Melakukan control output pekerjaan.

5. Meminta pelaporan secara berkala.

Sekretaris Dinas Pendidikan dan Kebudayaan juga memberikan gambaran tentang proses pengarahan dan pendelegasian wewenang dan tanggung jawab (proses komunikasi dan koordinasi) yaitu, dengan cara :

1. Setiap awal tahun anggaran pekerjaan yang ditangani pegawai kita evaluasi. Ada catatankah?

2. Kita lanjuti catatan tersebut. Pada prinsipnya, pekerjaan dalam bidang dilaksanakan secara bersama-sama walaupun tanggung jawab tetap kembali pada masing-masing pegawai.

3. Pendelegasian pekerjaan dengan proses pelimpahan wewenang secara struktural yang berasal dari Kepala Dinas $=>$ Sekretaris Dinas => Kepala Bidang => Kepala Seksi => Pegawai. (Wawancara, 6 Agustus 2018)

\section{Pendidikan Pegawai}

Pendidikan pegawai (employee education) yaitu kegiantan-kegiatan pendidikan atau pelatihan yang bersifat promosi dan pengembangan karier bagi para pegawai. Oleh sebab itu fokus pada pendidikan pegawai ini adalah 
pengembangan kemampuan individual pegawai maka akan dilihat dari tingkat kedisiplinan pegawai dalam penelitian ini.

Pembinaan disiplin dapat dikembangkan dengan cara kepemimpinan yang dapat dijadikan panutan atau teladan bagi para bawahan. Didepan memberi teladan, ditengah selalu membangkitkan semangat kerja dan dibelakang selalu bertindak sebagai motivator.

Moekijat (1999:138) apabila pegawai merasa berbahagia dalam pekerjaannya, pada umumnya hal itu didorong oleh disiplin pribadi mereka sendiri, dan sebaliknya apabila moril atau semangat kerja rendah, maka mereka tergolong orang yang dapat menyesuaikan diri dengan kebiasaan-kebiasaan yang tidak baik, sebagai contoh menggunakan banyak waktu sekedar minum kopi, datang terlambat, atau mungkin menyetujui perintah atasan dengan hati yang tidak senang.

Pembinaan Disiplin mengenai absensi diartikan sebagai sikap atau prilaku pegawai negeri yang menunjukkan kedisplinan terhadap kehadiran dan kepatuhan pegawai pada Dinas Pendidikan dan Kebudayaan Kabupaten Kolaka Utara dengan hadir setiap hari selama 1 (satu) minggu pada hari kerja. Disiplin waktu kehadiran adalah kesadaran dan kesediaan seseorang mentaati semua peraturan dan norma-norma social yang berlaku dalam organisasi. Kesadaran dan kesediaan ini merupakan sikap seseorang yang secara sukarela mentaati semua peraturan terutama kehadiran dan sadar akan serta tugas jawabnya sebagai seorang (public service) pelayanan masyarakat.

Dinas Pendidikan dan Kebudayaan Kabupaten Kolaka Utara selaku instansi pemerintahan, selalu berupaya agar para pegawai dapat mentaati segala peraturan yang ditetapakan pada Dinas Pendidikan dan Kebudayaan Kabupaten Kolaka Utara terutama kehadiran, untuk dapat merealisasikan hal tersebut, maka pimpinan dalam hal ini Kepala Dinas senantiasa menghimbau kepada para pegawai agar hadir setiap hari dalam 1 (satu) minggu pada hari kerja. Dengan mentaati segala peraturan sehingga pelaksanaan tugas pokok pegawai di Dinas Pendidikan dan Kebudayaan Kabupaten Kolaka Utara dapat terlaksana secara efektif dan efisien. Untuk mengetahui tanggapan informan tentang kehadiran pegawai pada Dinas Pendidikan dan Kebudayaan Kabupaten Kolaka Utara oleh Bapak Ha, menjelaskan bahwa:

"kehadiran pegawai pada Dinas Pendidikan dan Kebudayaan Kabupaten Kolaka Utara, disini kami sangat memperhatikan kehadiran, kami selalu berupaya untuk hadir di kantor sesuai dengan aturan pada Dinas Pendidikan dan Kebudayaan Kabupaten Kolaka Utara. (Wawancara, 13 Agustus 2018) ungkapannya:

Selanjutnya Ibu Ju tentang Disiplin Kehadiran Pegawai, berikut “Tingkat kehadiran pegawai sangat baik, kami pegawai disini sangat memperhatikan kehadiran yaitu datang tepat waktu dan pulang kantor sesuai dengan waktu yang ditetapkan." (Wawancara, 13 Agustus 2018) 
Berikut Bapak HM dengan hal senada mengungkapkan bahwa:

"kalau masalah disiplin kehadiran pegawai pada Dinas Pendidikan dan Kebudayaan Kabupaten Kolaka Utara disini sangat disiplin pegawai selalu hadir setiap hari kerja sehingga banyak pekerjaan yang dapat diselesaikan. (Wawancara, 14 Agustus 2018)

Hal serupa juga diungkapkan oleh pegawai Dinas Pendidikan dan Kebudayaan Kabupaten Kolaka Utara oleh Ibu RM bahwa :

"kami selaku pegawai selalu disiplin mengenai kehadiran dengan hadir selama satu minggu pada hari kerja, untuk mengoptimalkan pelaksanaan tugas pokok kami. (Wawancara, 14 Agustus 2018)

Selanjutnya Bapak BB juga menyatakan pendapatnya tentang Disiplin Kehadiran pegawai, berikut pernyataannya:

"seluruh pegawai telah berupaya tepat waktu untuk hadir setiap hari ke kantor sesuai dengan jadwal yang ditetapkan, walaupun masih ada sebagian pegawai yang sering keluar pada jam kantor, hal ini karena pegawai mempunyai urusan pribadi. (Wawancara, 15 Agustus 2018)

Berdasarkan hasil wawancara di atas dapat disimpulkan bahwa disiplin tentang kehadiran pegawai pada Dinas Pendidikan dan Kebudayaan Kabupaten Kolaka Utara berada pada kategori baik. Pegawai sangat memperhatikan kehadiran dan hadir sesuai jadwal yang ditetapkan sehingga dapat mengoptimalkan tugas pokok dan fungsinya. Hal ini dapat mendukung terciptanya organisasi yang efektif dan efisien. Namun ada sebagian pegawai yang kurang disiplin, hal ini disebabkan karena pegawai mempunyai kesibukan yang menyangkut urusan pribadi sehingga menghambat dan mengakibatkan hasil kerja yang ditampilkan kurang maksimal.

Dinas Pendidikan dan Kebudayaan Kabupaten Kolaka Utara selaku instansi pemerintah, selalu berupaya agar pegawai dapat menaati segalah peraturan yang diterapkan pada Dinas Pendidikan dan Kebudayaan Kabupaten Kolaka Utara terutama kepatuhan terhadap jam kerja sehingga pelayanan terhadap masyarakat dapat berjalan dengan baik. Untuk dapat merealisasikan hal tersebut, maka pimpinan dalam hal ini Kepala Dinas senantiasa menghimbau kepada para pegawai agar hadir pukul 7.30, sehingga dapat menyiapkan segalah keperluan yang berkaitkan dengan pekerjaan dan pulang kerja pukul 16.00 Wita. Dengan menaati segalah peraturan dan menjalankan disiplin waktu, sehingga pekerjaan-pekerjaan di Dinas Pendidikan dan Kebudayaan Kabupaten Kolaka Utara dapat dilaksanakan dengan optimal.

Untuk mengetahui tanggapan responden tentang ketepatan terhadap jam kerja pegawai berikut ungkapan Bapak Ha mengatakan:

"ketepatan waktu pegawai pada Dinas Pendidikan dan Kebudayaan

Kabupaten Kolaka Utara sudah baik, karena pegawai sangat 
memperhatikan disiplin waktu kerja yaitu datang tepat waktu dan menyiapkan segenap keperluan kerja yang berkaitan dengan pekerjaan mereka. (Wawancara, 20 Agustus 2018).

Hal tersebut juga diungkapkan Bapak Ru pada Dinas Pendidikan dan Kebudayaan Kabupaten Kolaka Utara mengungkapkan bahwa:

"Menurut saya disiplin waktu pegawai disini sudah cukup baik dan sesuai aturan masuk kantor pukul 07.30 wita dan pulang kantor pukul 16.00, kami disini selalu berupaya menjalankan disiplin waktu dengan sebaikbaiknya." (Wawancara, 20 Agustus 2018)

Dengan demikian ketepatan waktu pada Dinas Pendidikan dan Kebudayaan Kabupaten Kolaka Utara berada pada kategori baik, hal ini terlihat pada pegawai yang memperhatikan disiplin waktu kerja yaitu masuk kantor pukul 07.30 wita dan pulang kantor pukul 16.00 dan selalu melaksanakan disiplin waktu dengan baik.

Selanjutnya Bapak SI pada Dinas Pendidikan dan Kebudayaan Kabupaten Kolaka Utara mengatakan tentang ketepatan waktu bahwa :

"pegawai disini sangat disiplin dan pimpinan disini senantiasa menghimbau pegawai untuk selalu menerapkan disiplin waktu baik disiplin waktu hadir di kantor, pulang kantor maupun disiplin pelaksanaan pekerjaan mereka. (Wawancara, 20 Agustus 2018)

Berdasarkan hasil wawancara di atas dapat disimpulkan bahwa ketepatan waktu kerja pada Dinas Pendidikan dan Kebudayaan Kabupaten Kolaka Utara berada pada kategori baik hal ini terlihat pada pimpinan yang senantiasa menghimbau pegawai untuk selalu menerapkan disiplin waktu baik disiplin waktu hadir dan pulang kantor maupun disiplin waktu pelaksanaan pekerjaan dan terlihat pula pada pegawai yang memperhatikan ketepatan waktu kerja sehingga dapat menyelesaikan tugas sesuai yang diharapkan Pada Dinas Pendidikan dan Kebudayaan Kabupaten Kolaka Utara. Namun Sering dikunjungi beberapa pegawai yang terlambat masuk kantor karena tidak adanya pekerjaan yang mendesak untuk diselesaikan hal ini disebabkan karena pekerjaan yang menjadi beban tugasnya telah diselesaikan sebelumnya.

Pegawai pada Dinas Pendidikan dan Kebudayaan Kabupaten Kolaka Utara senantiasa patuh dan taat pada peraturan yang berlaku, Dinas Pendidikan dan Kebudayaan menetapkan peraturan kepada pegawai yang bertujuan untuk meningkatkan tingkat disiplin pegawainya. Untuk mengetahui tanggapan informan tentang disiplin dalam ketaatan pada peraturan berikut pernyataan Bapak MI mengatakan bahwa:

"ketaatan pegawai terhadap peraturan pada Dinas Pendidikan dan Kebudayaan Kabupaten Kolaka Utara kami sangat taat. kami bekerja berdasarkan peraturan yang ditetapkan dan menggunakan peralatan yang telah di sediakan serta memelihara sarana dan prasarana dengan sebaikbaiknya." (Wawancara, 21 Agustus 2018) 
Hal serupa juga diungkapkan oleh Ibu Ju mengungkapkan bahwa:

"para pegawai di sini selalu taat pada peraturan kantor dan selalu melaksanakan tugas dengan sungguh-sungguh sehingga pelaksanaan tugas pokok dan fungsi masing-masing pegawai dapat dilaksanakan dengan tepat waktu" (Wawancara, 21 Agustus 2018)

Dengan demikian pembinaan disiplin dalam ketaatan terhadap peraturan pada Dinas Pendidikan dan Kebudayaan Kabupaten Kolaka Utara berada pada kategori baik, hal ini terlihat pada pegawai yang selalu patuh pada peraturan yang telah ditetapkan dan bekerja menggunakan sarana yang ada serta melaksanakan tugas dengan sungguh-sungguh.

Selanjutnya Ibu Ra pada Dinas Pendidikan dan Kebudayaan Kabupaten Kolaka Utara mengatakan bahwa:

"kalau masalah taat kami selalu taat pada peraturan kantor kami bekerja Berdasarakan prosedur kerja dan bekerja dengan sungguh-sungguh berdasarkan tugas pokok kami." (Wawancara, 22 Agustus 2018)

Hal ini pula di kemukakan oleh Bapak Ma pada Dinas Pendidikan dan Kebudayaan Kabupaten Kolaka Utara yaitu sebagai berikut :

"pegawai yang taat merupakan pegawai yang melaksanakan pekerjaannya dengan sebaik-baiknyadan menggunakan kemampuan yang dimilikinya serta senantiasa menjaga kelancaran kerja dan kami disini selalu berusaha mentaati dan mematuhi peraturan kantor." (Wawancara, 22 Agustus 2018)

Berdasarkan hasil wawancara di atas dapat disimpulkan bahwa pembinaan disiplin dalam ketaatan pada peraturan kerja, pegawai pada Dinas Pendidikan dan Kebudayaan Kabupaten Kolaka Utara telah berjalan dengan baik, hal ini ditinjau dari para pegawai yang selalu menaati dan mematuhi peraturan dengan sebaik-baiknya sehingga dapat menunjang kegiatan kantor berjalan dengan lancar, serta adanya kesanggupan para pegawai dalam menghadapi pekerjaan yang menjadi tanggung jawabnya.

\section{Pengembangan Pegawai}

Pengembangan Pegawai (employee develompment) yaitu kegiatan pendidikan atau pelatihan pegawai yang di tujukan kepada pengembangan, pertumbuhan, perbahan departemen atau unit-unit kerja departement. Melalu kegiatan ini para pegawai berkembang secara fleksibel seirama perkembangan ke masa depan.

Salah satu upaya dalam pengembangan pegawai di Dinas Pendidikan dan Kebudayaan Kabupaten Kolaka Utara ditempuh melalui bimbingan teknis dan diklat. Upaya yang dilakukan dengan mengikutsertakan atau mengirim pegawai untuk mengikuti diklat atau kursus. Hal ini bertujuan untuk membekali pegawai dengan kompetensi yang harus dikuasai agar penyelesaian pekerjaan dapat dilakukan dengan baik. Kesempatan diberikan jika ada program yang relevan dengan tugas pokok dan fungsi bidang pekerjaan. Program diklat atau bimbingan teknis yang ditawarkan biasanya berasal dari pihak eksternal antara lain Dinas Pendidikan Provinsi, Pemerintah Daerah Kabupaten Kolaka Utara, Perguruan 
Tinggi, ataupun LPMP. Pihak yang terkait antara lain yaitu, Sub Bagian Kepegawaian dan Bidang PMPTK.

Bimbingan teknis dan Diklat dilakukan setiap waktu jika adanya pendanaan dan kesempatan. Pelaksanaan berbagai kesempatan bimbingan teknis dan diklat pegawai bertempat di tempat yang ditentukan oleh penyelenggara. Pihak yang terlibat dalam program ini adalah stakeholder pendidikan terkait. Program dilaksanakan mulai bulan Januari sampai dengan Desember. Hal ini diungkapkan oleh Bapak BB dalam suatu kesempatan wawancara, yaitu,

"Diklat dan Bimbingan teknis itu dilakukan kalau ada kerja sama dengan pihak eksternal, Biasanya pihak LPMP atau Dikti. Rentang waktunya ya dari Januari sampai Desember kalau ada kesempatan dan dana. Dan yang relevan dengan tupoksi pastinya kami akan rekomendasikan bagi pegawai untuk mengikuti kegiatan pelatihan." (Wawancara, 22 Agustus 2018)

Untuk di berbagai bidang baik itu Bidang Pendidikan Dasar, Pendidikan Menengah, Pendidikan Non Formal, dan Peningkatan Mutu Pendidik dan Tenaga Kependidikan, kesempatan pegawai mengikuti diklat ataupun bimbingan teknis jika ada pihak yang bekerja sama. Kesempatan mengikuti diklat misalkan Diklat Pengadaan Barang dan Jasa, Diklat Keuangan, dan lainnya. Usaha peningkatan kompetensi pegawai di bidang teknologi juga merupakan hal yang penting. Untuk itulah diklat yang sering diikuti oleh pegawai antara lain pelatihan ICT, programer, maupun yang berbasis web.

Selain diklat teknis yang diikuti oleh pegawai, pimpinan Dinas Pendidikan dan Kebudayaan Kabupaten Kolaka Utara juga mengirimkan pejabat struktural untuk mengikuti Diklat Kepemimpinan (Diklatpim) yang dilaksanakan untuk memberikan pemahaman teoritis maupun praktis dalam mengelola organisasi. Diklat ini sudah diikuti sebagian besar pejabat struktural Dinas Pendidikan dan Kebudayaan Kabupaten Kolaka Utara. Diklatpim yang diikuti antara lain Diklat ADUM, Diklat SPAMA, dan Diklat SPAMEN.

Pentingnya kesempatan peningkatan kemampuan pegawai di Dinas Pendidikan dan Kebudayaan Kabupaten Kolaka Utara didasari pada penempatan pegawai di Dinas Pendidikan dan Kebudayaan Kabupaten Kolaka Utara belum sepenuhnya tersusun berdasarkan perencanaan pegawai yang komprehensif dan berbasis kinerja. Ada beberapa pegawai yang penempatannya belum sesuai dengan kompetensi jabatan. Hal ini dikarenakan proses penempatan pegawai diatur oleh Badan Kepegawaian dan Pengembangan SDM Kabupaten Kolaka Utara.

Pada kenyataannya, tidak semua pegawai mengerjakan pekerjaan sesuai dengan apa yang di harapkan oleh pimpinan. Hal ini menyebabkan pentingnya pembinaan pegawai untuk menghadapi berbagai masalah pekerjaan berdasarkan keahlian dan tupoksi pegawai. Bapak HM mengungkapkan pada suatu sesi wawancara, sebagai berikut:

"Penempatan pegawai selama ini diatur oleh Badan Kepegawaian dan Pengembangan SDM, Kami mengajukan permintaan, baru Badan Kepegawaian yang akan memproses formasi itu. Kalau kemampuan, saya 
rasa semua pegawai di bidang ini sudah cukup mampu menyelesaikan pekerjaan dengan baik. Karena mau belajar sehingga pekerjaan dapat di selesaikan. (Wawancara, 27 Agustus 2018)

Menurut salah satu informan Bapak Ma mengungkapkan hal yang sama bahwa

“Belum semua pegawai memiliki kompetensi yang dipersyaratkan. Proses penempatan pegawai dengan rekruitmen umum sesuai dengan formasi yang dibutuhkan, akan tetapi dalam kenyataan tidak sesuai dengan formasi awal" (Wawancara, 27 Agustus 2018)

Berdasarkan pada berbagai hambatan di penempatan pegawai tersebut, dibutuhkan kesempatan peningkatan kemampuan pegawai. Kesempatan peningkatan kemampuan pegawai di kantor Dinas Pendidikan dan Kebudayaan Kabupaten Kolaka Utara antara lain melalui bimbingan teknis, workshop, dan pelatihan-pelatihan. Kegiatan-kegiatan tersebut selama ini bergantung pada pihak eksternal. Belum ada upaya dari pihak internal kantor Dinas Pendidikan dan Kebudayaan Kabupaten Kolaka Utara. Belum adanya upaya ini disebabkan oleh keterbatasan dana yang diberikan untuk menyelenggarakan kegiatan peningkatan kompetensi pegawai.

Dari berbagai masalah tersebut, masih perlu dilakukan upaya pengembangan dan peningkatan kemampuan pegawai. Selama ini, pada kenyataannya upaya peningkatan kemampuan pegawai masih mengandalkan undangan pelatihan dari pihak eksternal Dinas Pendidikan dan Kebudayaan Kabupaten Kolaka Utara. Pihak eksternal itu sendiri antara lain Dinas Pendidikan Provinsi, Pemerintah Daerah Kabupaten Kolaka Utara, Perguruan Tinggi, dan LPMP. Sehingga diklat PNS yang bertujuan mengembangkan dan meningkatkan kemampuan pegawai di kantor Dinas Pendidikan dan Kebudayaan Kabupaten Kolaka Utara dirasa belum optimal. Seperti yang diungkapkan pada suatu sesi wawancara oleh Bapak MI mengenai kesempatan peningkatan pegawai,

"Peningkatan pegawai itu masih diperlukan. Sedangkan dari internal dinas sendiri belum ada upaya. Hanya mengandalkan undangan pelatihan dari luar dinas." (Wawancara, 27 Agustus 2018)

Upaya pengembangan dan peningkatan kemampuan melalui pemberian tugas secara khusus di Dinas Pendidikan dan Kebudayaan Kabupaten Kolaka Utara mulai dari awal bekerja, pegawai sudah disosialisasikan target kerja yang harus dicapai. Perlu adanya monitoring rutin akan hasil kerjanya, sehingga akan membantu pegawai tersebut lebih lagi meningkatkan kinerjanya. Jika ada kekurangan, maka dapat disampaikan hal-hal yang perlu pegawai lakukan untuk mengatasi kekurangan tersebut. Demikian juga jika ternyata pegawai tersebut berhasil mencapai target yang lebih, maka dapat ditingkatkan lagi target kerjanya. Dengan adanya orientasi pegawai tersebut diharapkan dapat membantu pegawai untuk bekerja dengan baik, dapat meningkatkan produktivitas kerjanya, yang pada akhirnya akan mendukung pencapaian tujuan Dinas Pendidikan dan Kebudayaan Kabupaten Kolaka Utara.

Bapak Ru menjelaskan bahwa 
“Upaya yang dilakukan dihadapkan dengan berbagai keterbatasan tersebut melalui memotivasi pegawai untuk belajar mandiri, secara otodidak. (Wawancara, 28 Agustus 2018)

Motivasi pegawai yang diberikan oleh pimpinan disampaikan di berbagai kesempatan. Peningkatan kompetensi tetap diperlukan dengan memberi motivasi dan belajar serta berlatih tentang informasi baru dalam peningkatan perkembangan teknologi informasi. Hal yang senada disampaikan oleh Bapak HL bahwa:

“Upaya yang dilakukan melalui mendorong pegawai untuk belajar mandiri, melalui tutorial ataupun modul yang ada misalkan yang berasal dari internet. (Wawancara, 28 Agustus 2018)

Dinas Pendidikan dan Kebudayaan Kabupaten Kolaka Utara sudah memfasilitasi jaringan sistem online sehingga pegawai diharapkan mampu belajar secara mandiri. Berikut kutipan wawancara dengan Bapak MI tentang motivasi peningkatan kemampuan pegawai:

“Kami memotivasi pegawai, Agar pegawai mau belajar dan berlatih secara mandiri. Khususnya penguasaan di IT. Hal ini menjadi sangat penting di Bidang Pendidikan Menengah. Berbagai program berbasis komputerisasi semua." (Wawancara, 28 Agustus 2018)

Lebih lanjut dikatakan bahwa:

“Belajar mandiri itu sangat penting. Ada kan ya tutorial atau modul yang bisa di searching di internet. Kalau pelatihan bergantung dengan eksternal, biasanya usaha rutin yah baca-baca sama praktek sendiri, Belajar sama coba-coba. Jaringan internet di kantor bisa dimaksimalkan." (Wawancara, 28 Agustus 2018)

Usaha peningkatan kompetensi pegawai harus selalu dilakukan. Kepala Dinas Pendidikan dan Kebudayaan Kabupaten Kolaka Utara mengungkapkan bahwa peningkatan kompetensi pegawai harus selalu dilakukan dikarenakan tuntutan dan aturan yang harus disesuaikan dimana peningkatan kerja merupakan hal yang paling penting. Upaya yang dilakukan pimpinan dengan menumbuhkan selalu semangat kerja dikarenakan kantor Dinas Pendidikan dan Kebudayaan Kabupaten Kolaka Utara merupakan Satuan Kerja Perangkat Daerah (SKPD) yang terbilang cukup besar dan hal tersebut menyebabkan mobilitas yang sangat tinggi. Untuk meningkatkan semangat kerja, Kepala Dinas Pendidikan dan Kebudayaan Kabupaten Kolaka Utara membangun komunikasi yang baik sehingga nantinya dalam pengenalan, pendekatan pribadi akan terjalin harmonis. Suasana harmonis tersebut diharapkan tercipta baik di dalam jam dinas maupun diluar jam dinas.

"Sering kali pekerjaan selesai diluar jam formal, Kenal dulu lebih penting. Jadi kalau sudah kenal, mau menyuruh atau tegur akan lebih baik jika kenal lebih dulu." (Wawancara, 28 Agustus 2018)

Keterbatasan kesempatan peningkatan kemampuan pegawai di Dinas Pendidikan dan Kebudayaan Kabupaten Kolaka Utara yang hanya mengandalkan pihak eksternal juga ditempuh dengan upaya lain. Upaya lain tersebut dengan mengikutsertakan pegawai dalam rapat koordinasi. Rapat koordinasi tersebut di 
berbagai lingkup baik itu lingkup interen maupun lintas sektoral. Pimpinan mengirimkan pegawai untuk rapat koordinasi secara internal maupun eksternal dengan tujuan menambah kemampuan pegawai, kemandirian pegawai, serta wawasan pegawai yang tidak hanya di lingkup interen Dinas Pendidikan dan Kebudayaan Kabupaten Kolaka Utara. Selain rapat koordinasi, pimpinan memberi kesempatan peningkatan akademis (studi lanjut) bagi pegawai. Peningkatan akademis tersebut diijinkan dengan syarat tidak mengganggu kinerja pegawai dalam melaksanakan tanggung jawab mereka.

Berbagai upaya pimpinan untuk meningkatkan kemampuan pegawai dibenarkan oleh Pegawai Seksi Pembinaan Kursus dan Pelatihan yang diwawancarai dalam sebuah kesempatan. Pegawai Seksi Pembinaan Kursus dan Pelatihan mengungkapkan bahwa kesempatan peningkatan kompetensi perlu dilakukan, dan usaha yang telah dilakukan antara lain:

1. Diklat mengenai tugas dan pokok kerja.

2. Pemberian motivasi untuk mendorong pegawai berlatih dan belajar secara mandiri.

3. Pelatihan mengenai teknologi terbaru.

4. Selain itu, pemberian kebebasan kuliah lagi. (Wawancara, 28 Agustus 2018)

\section{Kesimpulan}

Berdasarkan hasil penelitian dan pembahasan mengenai pembinaan pegawai dalam melaksanakan Tugas Pokok dan Fungsi di Dinas Pendidikan dan Kebudayaan Kabupaten Kolaka Utara, dapat disimpulkan bahwa pelaksanaan pembinaan belum terlaksana dengan baik yang dilihat dari pembinaan Pendidikan dan Pelatihan yang dikarenakan masih ada penempatan pegawai yang tidak sesuai dengan latar belakang pendidikan.

Pelatihan pegawai dilakukan dengan pembagian orientasi kerja dengan memperhatikan kemampuan, kecermatan, dan ketepatan pegawai dalam menyelesaikan apa yang diberikan oleh pimpinan. Pendidikan pegawai sangat memperhatikan kehadiran dan hadir sesuai jadwal yang ditetapkan sehingga dapat mengoptimalkan tugas pokok dan fungsinya, begitu pula dengan ketetapan waktu jam kerja sudah dilaksanakan dengan baik namun masih ada pegawai yang selalu keluar dijam kerja atau ada urusan pribadi. Pengembangan pegawai peningkatan kemampuan pegawai masih mengandalkan undangan pelatihan dari pihak eksternal Dinas Pendidikan dan Kebudayaan Kabupaten Kolaka Utara serta masih ada pegawai yang penempatannya belum sesuai dengan kompetensi jabatan.

Untuk itu di sarankan sebaiknya para pengambil kebijakan di pemerintah daerah Kabupaten Kolaka untuk memberikan kesempatan kepada pegawai mengikuti pendidikan dan pelatihan yang sifatnya eksternal yang ada hubungannya dengan tugas pokok fungsinya sebagai pegawai.

\section{Daftar Pustaka}

Arsyad L. (2004). Ekonomi Pembangunan. Edisi Keempat. Yogyakarta: STIEKPN 
Foster. (2001). Pembinaan Untuk Peningkatan Kinerja Karyawan. Jakarta: PPM.

Hamjadid, (2010), Manajemen Pengembangan Sumber Daya Manusia di Dinas Pendidikan dan Kebudayaa, Kolaka Utara.

Hasibuan. (2007). Manajemen Sumber Daya Manusia. Jakarta: PT. Bumi Aksara.

Husnan, Suad, (2002), Manajemen Keuangan, Yogyakarta, Gajahmada Yogyakarta

Kirom, Bahrul, (2015), Mengukur Kinerja Pelayanan dan Kepuasan Konsumen, Bandung,Pustaka Reka Cipta

Mahmudi. (2005). Manajemen Kinerja Sektor Publik. Yogyakarta: UPP AMP. YKPN.

Mangkunegara, Anwar Prabu (2005). Sumber Daya Manusia Perusahaan Remaja. Bandung: Rosidakarya.

Matutina, dan Domi C. (1994). Manajemen Personalia. Jakarta: Rineka Cipta.

Miles, Matheu, dan Huberman, A.M. (1992). Analisis Data Kuantitatif:Buku Sumber Tentang Metode-Metode Baru. Jakarta: UI Pres.

Nazir, Moh, (2011), Metode Penelitian, Jakarta, Ghalia Indonesia

Notoatmojo, Soekidjo, 2003, Pengembangan Sumber Daya Manusia, Jakarta, Rineka Cipta

Poerwadarminta. (1987). Kamus Umum Bahasa Indonesia. Jakarta: Balai Pustaka.

Ruky. (2004). System Manajemen Kinerja. Jakarta: PT. Gramedia Pustaka Utama.

Sedarmayanti. (2001). Sumber Daya Manusia dan Produktivitas Kerja. Jakarta: Mandar Maju.

Sudjana, N. (2004). Dasar-Dasar Proses Belajar Mengajar. Bandung: Sinar.

Sugiyono. (2016). Metode Penelitian Kuantitatif, Kualitatif, dan RED. Bandung: Alfabeta.

Sukirman, Hartati, (2009), Administrasi dan Supervisi Pendidikan, Yogyakarta, UNY Press

Sulistiyani dan Rosidah. (2003). Manajemen Sumber Daya Manusia. Yogyakarta: Graha Ilmu.

Uno, Hamzah D, dan Nina L. (2012). Teori Kinerja dan Pengukurannya. Jakarta: Bumi Aksara.

Yuniarsih, Tjutju, (2009), Manajemen Sumber Daya Manusia, Bandung, Alfabeta 